\title{
Internal Migration and Contraceptive Knowledge And Use in Guatemala
}

By David P. Lindstrom and Coralia Herrera

Hernández

David P. Lindstrom is associate professor, Department of Sociology and Population Studies and Training

Center, Brown University, Providence, RI, USA. Coralia Herrera Hernández is a graduate student, El Colegio de Mexico, Mexico City.

\begin{abstract}
CONTEXT: Levels of modern contraceptive knowledge and use among people living in rural areas of Guatemala differ substantially from those of people living in urban areas. Understanding the pace and extent of rural-to-urban migrants' adoption of urban contraceptive practices is important in determining if there is a strong need for migrant-focused reproductive health programs.
\end{abstract}

METHODS: Bivariate and multivariate analyses of data on 971 married male and female respondents in the 1999 Guatemalan Migration and Reproductive Health Survey were used to examine how migration status and duration of residence in an urban area are associated with knowledge of modern contraceptive methods and current contraceptive use.

RESULTS: Migrants' contraceptive knowledge was positively associated with the number of years they had lived in an urban area. Mayan migrants in Guatemala City did not accumulate contraceptive knowledge at the same rate as nonMayan migrants, perhaps due to cultural and linguistic barriers to obtaining knowledge of and access to contraceptives. Rural-to-urban migrants eventually achieve a level of modern contraceptive use slightly below that of urban nonmigrants, with the level of contraceptive knowledge being an important factor associated with use of modern methods.

CONCLUSIONS: Migrants possess limited knowledge of modern contraceptive methods and, therefore, may experience unmet need for contraception or may have a limited choice of modern contraceptive methods during their first years in an urban destination. Programs designed to raise contraceptive awareness and use should target recent migrants - particularly indigenous Mayans — in urban areas.

International Family Planning Perspectives, 2006, 32(3):146-153.
Guatemala is a predominantly rural country with among the lowest levels of awareness and use of modern contraceptives, and one of the highest levels of fertility, in Latin America. Rural-urban differences in contraceptive use and total fertility are substantial: Twenty-six percent of rural women aged 15-49 use a modern contraceptive method, compared with $47 \%$ of urban women, and the total fertility rate in rural areas is 5.2 children per woman, compared with 3.4 in urban areas. ${ }^{1}$

Guatemala is also an ethnically divided country. Indigenous Mayans constitute approximately half of the population, with Ladinos-people of mixed European and indigenous ancestry-making up the other half. The Mayan population consistently scores below the Ladino population on common indicators of socioeconomic well-being and health. Mayans have particularly low levels of awareness and use of modern contraceptives: Of married women aged 15-49, 17\% of Mayans use a modern method, compared with $43 \%$ of Ladinos. ${ }^{2}$ Cultural and linguistic factors are the principal barriers to contraceptive use in the indigenous population, although access is also a problem in the more remote areas of the country. ${ }^{3}$

Migration from rural areas into towns and cities is slowly but steadily shifting the rural-urban balance of the pop- ulation, giving Guatemala Latin America's highest projected rate of urban growth. It is projected that by 2015 , more than $50 \%$ of Guatemala's population will live in urban areas. ${ }^{4}$ Given the substantial differences in rural and urban fertility practices, the gradual redistribution of the population from rural to urban areas could have an important effect on the future rate of population growth.

In this study, we use survey data to examine the pace at which and extent to which individuals who migrate from rural to urban areas of Guatemala attain urban levels of modern contraceptive knowledge and use. Also, we explore whether the relationship between migration experience and contraceptive knowledge and use differs between Mayans and Ladinos.

\section{BACKGROUND}

The fertility behavior of rural-to-urban migrants in urbanizing countries has been extensively studied by demographers because of its potential to accelerate the rate of population growth in urban areas. ${ }^{5}$ In addition, studies have examined migrant reproductive health and health services utilization in destination areas. ${ }^{6}$ Contraceptive awareness and use among migrants, however, has not been well studied, even though it is a key determinant of fertility and re- 
productive health. ${ }^{7}$ This lack of attention is due, in part, to the relative scarcity of surveys that collect both detailed migration histories and data on contraceptive knowledge and use. For example, the 2002 Guatemalan National Survey of Maternal and Infant Health does not include any questions on migration, and the 1995 and 1998-1999 versions of the same survey record place of birth, but not duration of stay in current place of residence. ${ }^{8}$

Migrants' contraceptive awareness and use has relevance not only for the pace of fertility change in urban areas, but also for the pace of fertility change in rural places of origin and for the spread of STIs, including HIV. The pace at which migrants from rural areas acquire contraceptive knowledge and experience in their urban destinations clearly affects their ability to control their fertility in response to the new opportunities and constraints they encounter. In addition, migrant populations are often considered to be an important vector for the spread of HIV. ${ }^{9}$ Finally, because rural-tourban migrants often remain in close contact with nonmigrant family and friends, they can play a role in the diffusion of urban contraceptive knowledge and fertility practices to their rural communities of origin. ${ }^{10}$ For example, in an analysis of health survey data collected in rural Guatemala, having kin who had migrated to urban areas or to other countries was associated with greater contraceptive knowledge and a greater likelihood of modern method use. ${ }^{11}$

Rural-to-urban migration can affect modern contraceptive knowledge and use through changes in both supply and demand for contraceptives. Urban areas provide greater exposure to information about family planning through print and broadcast media, and they provide a greater range and supply of family planning services and distribution outlets than rural areas. Migrants to urban areas, however, do not immediately have improved access to information and services, but rather accumulate knowledge over time as they learn more about their new environment and expand their range of social contacts. Therefore, we would expect a migrant's level of contraceptive knowledge to increase with length of stay in an urban area.

Migration also entails a change in the social and economic context of family life that affects the desire for additional children and the demand for contraceptive methods and services. In moving to towns and cities, migrants from rural areas-especially women-encounter increased family maintenance costs, increased access to education, a wider array of consumer goods and more widespread income opportunities. The constraints on family size imposed by the higher costs of raising children and the opportunity costs that occur if women forgo earning wages to raise large families are encountered by migrant couples from the time of arrival, or in the case of single migrants, at the outset of family formation. Because contraceptive learning may lag behind the demand for birth control, migrants may experience a period of unmet contraceptive need, or adopt an unsuitable method because they must choose from the limited set of contraceptive options with which they are familiar. With time, we expect the urban context of contraceptive supply and demand to produce levels of modern contraceptive knowledge and use among rural-to-urban migrants higher than those of rural nonmigrants, and similar to those of their nonmigrant urban neighbors. A strong relationship between contraceptive use and duration of stay in urban areas is consistent with a gradual process of migrant adaptation.

In examining the relationship between rural-to-urban migration and contraceptive knowledge and use, we need to consider the possibility of selectivity. Migrants are not randomly drawn from the populations in which they originally live, but rather are often selected for attributes that are associated with desired family size and contraceptive use. This positive selection may occur according to observable characteristics such as age and education, as well as unobserved characteristics such as mobility aspirations, tolerance for risk and openness to innovation. In our analysis, we control for social and demographic characteristics that are important predictors of fertility intentions and contraceptive awareness and use, and we include a dummy variable for migration status to control for migrant selectivity along unobserved characteristics. Findings of significantly higher contraceptive knowledge and use among migrants compared with rural nonmigrants, along with weak or insignificant duration effects, would be consistent with positive migrant selectivity.

\section{METHODS \\ Data}

The data for this study come from the 1999 Guatemalan Migration and Reproductive Health Survey, which was part of a four-nation comparative study on internal migration designed to identify the impact of rural-to-urban migration experience on change in women's reproductive behavior and health status. The survey used household and individual questionnaires to collect detailed data on migration and reproductive health in 24 purposively selected locations in Guatemala, including the Guatemala City metropolitan area, Quetzaltenango, and selected towns and villages (Table 1, page 148). In Guatemala City and Quetzaltenango, selected neighborhoods were sampled, whereas in the towns and villages, the entire population was sampled.

The areas were chosen to provide a diversity of migrant places of origin and destination, with different ethnic compositions and development levels. The Guatemala City metropolitan area has more than two million inhabitants and is by far the most important destination for urban-bound migrants from rural areas. The seven neighborhoods included in the study range from very poor to middle class, and encompass different stages of migrant settlement, from recently arrived migrants to well-established migrants. Quetzaltenango, the country's second largest city, is also a major destination for migrants from the predominantly indigenous western highland area of the country; households were sampled from the central zone of the city, which has an ethnically and socially diverse population. Five towns from three areas of the country were selected because they are migrant destinations for local rural populations, as well as 


\begin{tabular}{|c|c|c|c|}
\hline Sample location & Population & $\begin{array}{l}\text { No. of } \\
\text { households } \\
\text { sampled }\end{array}$ & $\begin{array}{l}\text { No. of } \\
\text { respondents } \\
\text { in analysis }\end{array}$ \\
\hline \multicolumn{4}{|l|}{ Metropolitan area } \\
\hline $\begin{array}{l}\text { Guatemala City (7 } \\
\text { neighborhoods) }\end{array}$ & $>2$ million & 447 & 223 \\
\hline \multicolumn{4}{|l|}{ Small city } \\
\hline $\begin{array}{l}\text { Quetzaltenango } \\
\text { (central zone) }\end{array}$ & 100,000 & 312 & 147 \\
\hline \multicolumn{4}{|l|}{ Towns } \\
\hline \multicolumn{4}{|l|}{ Santa Rosa } \\
\hline $\begin{array}{l}\text { (3 towns) } \\
\text { Zacapa }\end{array}$ & $\begin{array}{l}5,000-15,000 \\
5,000-15,000\end{array}$ & $\begin{array}{l}272 \\
250\end{array}$ & $\begin{array}{l}135 \\
109\end{array}$ \\
\hline Santa Cruz de Quiché & $5,000-15,000$ & 163 & 95 \\
\hline \multicolumn{4}{|l|}{ Rural communities } \\
\hline Santa Rosa (2 villages) & $100-500$ & 114 & 57 \\
\hline Zacapa (3 villages) & $100-500$ & 164 & 76 \\
\hline Quiché (6 villages) & $100-500$ & 221 & 129 \\
\hline Total & na & 1,943 & 971 \\
\hline
\end{tabular}

important sources of migrants for Guatemala City. Three towns were selected from the department of Santa Rosa, which is located on the Pacific coast and is an important zone of commercial agriculture. The towns of Zacapa and Santa Cruz de Quiché are important regional markets and administrative centers, located in the predominantly Spanish-speaking northeast and the western highlands, respectively. Finally, 11 villages and hamlets were selected: one village near each of two towns in Santa Rosa, three villages near Zacapa and six villages near Santa Cruz de Quiché.

Work in each location began with the construction of a sampling frame based on a street-by-street enumeration of all residences. Listed residences were numbered and randomly selected for interviewing. Bilingual (Spanish-Mayan Kich'e) interviewers were used in the study areas populated predominantly by indigenous Mayan speakers. For each selected residence, the interviewer collected a complete migration history for the head of the household; in households headed by couples, interviewers randomly selected either

\begin{tabular}{|c|c|c|c|c|}
\hline \multirow[t]{2}{*}{ Modern method } & \multicolumn{2}{|c|}{$\begin{array}{l}1999 \text { Migration and } \\
\text { Reproductive Health Survey }\end{array}$} & \multicolumn{2}{|c|}{$\begin{array}{l}\text { 1998-1999 National Survey of } \\
\text { Maternal and Infant Health }\end{array}$} \\
\hline & $\begin{array}{l}\text { Rural } \\
(\mathrm{N}=262)\end{array}$ & $\begin{array}{l}\text { Urban } \\
(\mathrm{N}=709)\end{array}$ & $\begin{array}{l}\text { Rural } \\
(\mathrm{N}=2,271)\end{array}$ & $\begin{array}{l}\text { Urban } \\
(\mathrm{N}=1,693)\end{array}$ \\
\hline None & 80.5 & 59.5 & 78.6 & 56.5 \\
\hline Pill & 5.0 & 7.2 & 2.9 & 7.8 \\
\hline IUD & 1.1 & 5.4 & 1.0 & 3.7 \\
\hline Injectable & 3.4 & 7.1 & 3.3 & 4.6 \\
\hline Condom & 1.9 & 2.7 & 1.7 & 3.1 \\
\hline Female sterilization & 7.0 & 16.1 & 12.2 & 22.7 \\
\hline Male sterilization & 1.1 & 1.4 & 0.3 & 1.5 \\
\hline Other & 0.0 & 0.6 & 0.0 & 0.1 \\
\hline Total & 100.0 & 100.0 & 100.0 & 100.0 \\
\hline
\end{tabular}

the husband or the wife. In addition to the migration histories, the study collected information on contraceptive knowledge, current contraceptive use, and household and social background characteristics. The sample consisted of 1,943 households, with an approximate balance of individual interviews with currently married men and women.

A weakness of the sample is that it did not include remote rural communities, although migrants from these places who were residing in urban areas were included in the sampled urban areas. ${ }^{*}$ Overall, the sample is underrepresentative of rural areas: Roughly two-thirds of all households in Guatemala are in rural areas, compared with around one-quarter of the households in the sample. Because contraceptive knowledge and use are lowest in rural areas, especially in remote rural areas, we are likely to underestimate the full effect of the urban migration experience on increasing migrant contraceptive knowledge and use beyond the levels of rural nonmigrants. The survey does not include weights, nor do we attempt to develop weights to adjust for the oversampling of urban areas.

\section{Analysis}

For our analysis, we used data collected from currently married women aged 15-49 and from men currently married to women aged 15-49; ${ }^{\dagger} 972$ households were excluded due to our age and marital criteria. In 97 households, both the husband and the wife were interviewed; in those cases, we randomly excluded one of the marital partners from the analytic sample. Thus, from the 1,943 households, we used data from 971 married women and men.

Whether the sample is representative of the overall population is always an issue for studies based on purposively selected communities. As we mentioned above, our sample overrepresents urban areas. For comparison purposes, we present the distribution of current contraceptive use in rural and urban areas for the married men and women in our sample and for married women from the 1998-1999 Guatemalan National Survey of Maternal and Infant Health (Table 2). The levels of use of specific methods in rural and urban areas in our sample are remarkably close to those in the Guatemalan National Survey sample. The one exception is female sterilization, which is less prevalent in our sample. One possible explanation for this difference is that married men underreport their wife's sterilization as a current contraceptive method. Because we include place of residence as a variable in our regression models, we are likely to minimize any bias in our estimates due to the undersampling of rural areas by the Guatemalan Migration and Reproductive Health Survey.

We used information from the migration histories to divide the sample into three groups by migration status: rural nonmigrants, rural-to-urban migrants and urban nonmigrants. Rural nonmigrants include women and men na-

*We define places with 2,500 inhabitants or more as urban.

tIn this article, we treat consensual and formal unions as marriages, and include a dummy variable for union type in our regression models. 
tive to the rural area in which they live (rural natives), those who have moved from other rural areas (rural-to-rural migrants) and those who have lived in other areas but returned to their rural place of origin (rural-return migrants). Ruralto-urban migrants are individuals born in rural places residing in urban areas at the time of the survey. Urban nonmigrants include those native to the urban area in which they live (urban natives), those who have moved from other urban areas (urban-to-urban migrants) and those who have lived in other areas but returned to their urban place of origin (urban-return migrants).

Our two dependent variables of interest are knowledge and current use of modern contraceptive methods. First, we estimated a negative binomial regression model* to examine the determinants of knowledge about modern contraceptives in our sample. Then, we excluded from the sample women who were pregnant at the time of the survey and men married to such women, and estimated a logistic regression model to identify the factors associated with current contraceptive use. In each case, we began with a simple model that included only migration variables, to formally test for significant bivariate differences in contraceptive knowledge and contraceptive use by place of residence and migration status. Then, we added variables for social and demographic characteristics (ethnicity, age, age-squared, ${ }^{\dagger}$ gender, education, working status of the woman or wife, union status and the number of surviving children), duration of stay in an urban area and other measures to the models, to examine the pace of contraceptive learning and migrant adaptation, controlling for migrant selectivity.

In an analysis of migration and contraceptive use based on Demographic Health Survey data from 14 African countries, contraceptive use among rural-to-urban migrants rose sharply in the second and third years after moving to the city. ${ }^{12}$ Thus, we included variables to measure the association between duration of stay in an urban area and current contraceptive use. Ideally, we would have used a series of dummy variables corresponding to relatively short intervals, but because of our small sample size, we used two dummy variables corresponding to recent migrants (1-5 years) and settled migrants (six or more years). If migrants to Guatemala City are positively selected for modern contraceptive use, then we would expect little difference between recent and settled migrants, net of other effects. On the other hand, if migrants gradually adjust to urban conditions and adopt modern contraceptive methods at a slower pace, then we would expect the odds ratio for settled migrants to be substantially larger than the odds ratio for recent migrants.

\section{RESULTS}

There were substantial differences in the characteristics of the three migration groups (Table 3 ). Slightly more than half $(52 \%)$ of rural nonmigrants were Mayan, compared with one-quarter of rural-to-urban migrants and urban nonmigrants (26\% and $25 \%$, respectively). Some $55 \%$ of rural nonmigrants had no schooling, compared with $25 \%$ of
TABLE 3. Selected characteristics of currently married women and men aged 15-49, by migration status

\begin{tabular}{|c|c|c|c|}
\hline Characteristic & $\begin{array}{l}\text { Rural } \\
\text { nonmigrant } \\
(\mathrm{N}=262)\end{array}$ & $\begin{array}{l}\text { Rural-urban } \\
\text { migrant } \\
(\mathrm{N}=140)\end{array}$ & $\begin{array}{l}\text { Urban } \\
\text { nonmigrant } \\
(\mathrm{N}=569)\end{array}$ \\
\hline \multicolumn{4}{|l|}{$\begin{array}{l}\% \text { distributions } \\
\text { Gender }\end{array}$} \\
\hline Male & 55.0 & 55.7 & 46.9 \\
\hline Female & 45.0 & 44.3 & 53.1 \\
\hline \multicolumn{4}{|l|}{ Ethnicity } \\
\hline Mayan & 51.5 & 25.7 & 25.3 \\
\hline Ladino & 48.5 & 74.3 & 74.7 \\
\hline \multicolumn{4}{|l|}{ Education } \\
\hline None & 55.3 & 25.1 & 6.2 \\
\hline Primary & 26.7 & 41.4 & 27.6 \\
\hline Secondary & 8.8 & 12.1 & 24.6 \\
\hline Postsecondary & 9.2 & 21.4 & 41.6 \\
\hline \multicolumn{4}{|l|}{ Woman/wife works } \\
\hline Yes & 21.8 & 32.1 & 25.0 \\
\hline No & 78.2 & 67.9 & 75.0 \\
\hline \multicolumn{4}{|l|}{ Union type } \\
\hline Formal & 70.6 & 61.4 & 72.1 \\
\hline Consensual & 29.4 & 38.6 & 27.9 \\
\hline \multicolumn{4}{|c|}{ No. of surviving children } \\
\hline 0 & 5.3 & 7.1 & 4.7 \\
\hline $1-4$ & 58.7 & 69.3 & 69.3 \\
\hline$\geq 5$ & 36.0 & 23.6 & 26.0 \\
\hline \multicolumn{4}{|l|}{ Age at migration } \\
\hline $0-11$ & na & 36.4 & na \\
\hline $12-19$ & na & 22.2 & na \\
\hline$\geq 20$ & na & 41.4 & na \\
\hline \multicolumn{4}{|c|}{ Currently using a modern method } \\
\hline Yes & 19.5 & 35.7 & 41.5 \\
\hline No & 80.5 & 64.3 & 58.5 \\
\hline Total & 100.0 & 100.0 & 100.0 \\
\hline \multicolumn{4}{|l|}{ Means } \\
\hline Age & 34.7 & 35.5 & 36.7 \\
\hline $\begin{array}{l}\text { No. of modern } \\
\text { methods known }\end{array}$ & 0.7 & 17 & 14 \\
\hline
\end{tabular}

rural-to-urban migrants and $6 \%$ of urban nonmigrants; at the other extreme, $42 \%$ of urban nonmigrants reported postsecondary education, compared with $21 \%$ of rural-tourban migrants and 9\% of rural nonmigrants. Women's participation in the labor force was greatest among ruralto-urban migrants: Thirty-two percent of migrant women and the wives of migrant men worked outside of the home or in a family business, compared with $25 \%$ of urban nonmigrants and $22 \%$ of rural nonmigrants. Also, the proportion of respondents in consensual unions was higher among rural-to-urban migrants than among rural and urban nonmigrants. Approximately one-fourth of rural-to-urban migrants and urban nonmigrants had five or more surviving children, compared with about one-third of rural nonmigrants. Among rural-to-urban migrants, 64\% had first moved to an urban location when they were adolescents

*Negative binomial regression is appropriate for modeling count data in which the variance is greater than the mean, a condition known as overdispersion (source: Cameron AC and Trivedi PK, Regression Analysis of Count Data, Cambridge, UK: Cambridge University Press, 1998).

tWe included age-squared to allow the underlying rate of contraceptive learning to decline as women age and reach the end of their reproductive age span. In preliminary contraceptive use models, the age-squared term was not significant. We excluded it from the final models and used a simple linear term to control for age differences in contraceptive use. 

TABLE 4. Beta coefficients from negative binomial regression models estimating the
number of modern contraceptive methods known, by model

\begin{tabular}{|c|c|c|c|c|}
\hline Variable & Model 1 & Model 2 & Model 3 & Model 4 \\
\hline \multicolumn{5}{|l|}{ Migration } \\
\hline Rural nonmigrant (ref) & na & na & na & na \\
\hline \multicolumn{5}{|l|}{ Rural-urban migrant } \\
\hline In small urban area & $0.724^{* *}$ & $0.435^{*}$ & 0.292 & 0.296 \\
\hline In metro area & $0.948^{* *}$ & $0.689^{* *}$ & $0.487^{*}$ & $0.539^{*}$ \\
\hline \multicolumn{5}{|l|}{ Urban nonmigrant } \\
\hline In small urban area & $0.499^{*}$ & -0.014 & 0.032 & 0.036 \\
\hline In metro area & $1.083^{* *}$ & $0.651^{* *}$ & $0.679 * *$ & $0.608^{* *}$ \\
\hline Duration of stay in urban area & na & na & $0.011^{* *}$ & $0.010^{* *}$ \\
\hline \multicolumn{4}{|l|}{ Duration of stay in urban area $\mathrm{x}$} & 0.008 \\
\hline \multicolumn{5}{|l|}{ Social and demographic } \\
\hline Mayan & na & $-0.504^{* *}$ & $-0.509^{* *}$ & $-0.530^{* *}$ \\
\hline Mayan $x$ metro area & na & na & na & 0.319 \\
\hline \multicolumn{5}{|l|}{ Mayan $x$ duration of stay } \\
\hline in urban area x metro area & na & na & na & $-0.036^{*}$ \\
\hline Age & na & $0.071^{*}$ & $0.074^{*}$ & $0.080^{*}$ \\
\hline Age-squared & na & $-0.001^{*}$ & $-0.001^{* *}$ & $-0.001^{* *}$ \\
\hline Male & na & 0.195 & 0.203 & 0.206 \\
\hline \multicolumn{5}{|l|}{ Education } \\
\hline None (ref) & na & na & na & na \\
\hline Primary & na & 0.268 & 0.259 & 0.238 \\
\hline Secondary & na & $0.586^{* *}$ & $0.527^{* *}$ & $0.511^{* *}$ \\
\hline Postsecondary & na & $0.871^{* *}$ & $0.798^{* *}$ & $0.774^{* *}$ \\
\hline Woman/wife works & na & 0.049 & 0.062 & 0.067 \\
\hline Formal union & na & 0.115 & 0.090 & 0.076 \\
\hline \multicolumn{5}{|l|}{ Surviving children } \\
\hline 0 (ref) & na & na & na & na \\
\hline $1-4$ & na & 0.285 & 0.283 & 0.302 \\
\hline$\geq 5$ & na & 0.125 & 0.114 & 0.129 \\
\hline$\alpha$ & $0.757^{* *}$ & $0.488^{* *}$ & $0.474^{* *}$ & $0.458^{* *}$ \\
\hline Logpseudolikelihood & -1452.5 & -1383.5 & -1378.3 & -1375.0 \\
\hline
\end{tabular}

or adults, whereas $36 \%$ had moved as children.

On average, rural-to-urban migrants knew 1.7 modern methods, whereas urban nonmigrants knew 1.4 and rural nonmigrants knew 0.7 . The level of current contraceptive use for rural-to-urban migrants (36\%) was almost twice that for rural nonmigrants (20\%), but slightly less than that for urban nonmigrants (42\%).

\section{Multivariate Analysis}

- Contraceptive knowledge. In the first analytical model in Table 4, which included only the migration variables, urban nonmigrants living in small urban or metropolitan areas and urban-to-rural migrants had greater levels of contraceptive knowledge than did rural nonmigrants. Among respondents living in a metropolitan area, the number of modern methods known by migrants was slightly lower than the number known by nonmigrants; however, among those living in small urban areas, the result was reversed, with migrants knowing more methods than nonmigrants.

When social and demographic characteristics were added to the analysis (model 2), the association between being a migrant in a small urban area and the number of methods known was reduced by $40 \%$; being a nonmigrant in a small urban area became nonsignificant. In contrast, the contraceptive knowledge of rural-to-urban migrants and urban nonmigrants of Guatemala City area continued to be sig- nificantly greater than that of rural nonmigrants. These results are consistent with migrant learning and adaptation in urban areas, as well as with migrant selectivity.

In the third model, we included two variables of duration of stay to separate migrant learning and adaptation from the potential effect of selectivity. The first duration variable measured total years spent in an urban location. The second variable was an interaction term that compared the rate of contraceptive learning in Guatemala City with that in small urban areas. The main duration variable was positively associated with contraceptive knowledge; the interaction term, however, was nonsignificant. With the duration variables added to the model, the association between being a migrant in the metropolitan area and level of contraceptive knowledge decreased by $30 \%$; being a migrant in small urban areas was no longer significant.

These results suggest that migrants to small urban areas arrive with rural levels of contraceptive knowledge and then gradually acquire knowledge. On the other hand, migrants to Guatemala City appear to have better contraceptive knowledge than rural nonmigrants at the outset of migration and acquire additional knowledge over time. Migrants to the metropolitan area seem to acquire contraceptive knowledge at the same rate as migrants to smaller urban areas.

Finally, we ran a fourth model, which included a term testing for an interaction between Mayan ethnicity and ruralurban migrant status. This interaction term tested whether Mayan migrants in the metropolitan area were a highly selected group with greater contraceptive knowledge than expected (based on their background characteristics) or an especially disadvantaged group with less knowledge than expected. In addition, we included a three-way interaction term among Mayan ethnicity, duration of stay in an urban area and migration to the metropolitan area. This term tested whether Mayan migrants in the metropolitan area acquire contraceptive knowledge at a slower or faster pace than Ladino migrants. The Mayan-metro interaction was not statistically significant, indicating that Mayans who migrate to the metropolitan area are neither more nor less selected than Ladinos with respect to contraceptive knowledge. The three-way interaction, however, was negatively associated with contraceptive knowledge and, in fact, cancels out the positive effect of duration of stay in an urban area (i.e., for Mayan migrants, contraceptive knowledge does not increase with duration of stay in an urban area).

In part, this result may reflect the selective assimilation into the Ladino population of the fastest contraceptive learners among Mayan migrants. Mayan ethnicity in Guatemala constitutes a continuum based on cultural identity and language. Assimilation into Ladino culture and ethnic switching is not uncommon, particularly among rural-to-urban Mayan migrants. ${ }^{13}$ Although our definition of "Mayan" includes men and women who identify themselves as Ladino but grew up speaking a Mayan language, our sample likely includes assimilated Mayan migrants who identified themselves as Ladinos and did not report having ever learned a Mayan language. The selective assimilation of 
Mayan contraceptive learners into the Ladino population will result in a self-identified Mayan migrant population that is increasingly selected for low contraceptive knowledge as duration of stay in the metro area increases.

Our results for the ethnicity and duration interactions should be interpreted with caution, given the relatively small size of the sample and the fact that it is not representative at the metropolitan level. Nevertheless, the results provide evidence that Mayan women and men who migrate to Guatemala City increase their knowledge of modern contraceptive methods at a slower rate than Ladino migrants. Compared with Ladino nonmigrants, Mayan migrants appear to be triply disadvantaged with regard to contraceptive knowledge: They have lower levels of education, have lower initial levels of contraceptive knowledge (even after accounting for their lower education) and appear to take more time to acquire contraceptive knowledge, as indicated by the negative interaction between Mayan ethnicity and duration in a metro area. This important ethnic difference in contraceptive learning is consistent with the relative linguistic and cultural isolation of indigenous migrants in the metro area, and it suggests the importance of targeting Mayan migrants in particular for family planning services. - Current contraceptive use. In our initial model estimating the bivariate relationships between migration experience and current contraceptive use, the odds of currently using contraceptives were significantly higher for migrants to the metro area (odds ratio, 2.7-Table 5) and for urban nonmigrants in small urban areas and Guatemala City (2.6 and 4.4 , respectively) than for rural nonmigrants.

When social and demographic variables were included in the analysis (model 2), current contraceptive use was positively associated with education and having one or more surviving children (2.0-6.0) and negatively associated with Mayan ethnicity and older age ( 0.5 and 0.98 , respectively); these results are consistent with other studies. ${ }^{14}$ Although attenuated, the odds of current contraceptive use remained significantly higher for migrants and nonmigrants in the metropolitan area than those for rural nonmigrants, (1.9 and 2.7, respectively). Being a nonmigrant in a small urban area, however, was no longer associated with contraceptive use. This result is consistent with what we found in regard to contraceptive knowledge: The higher levels of contraceptive knowledge and use in small urban areas than in rural areas may be attributable to compositional differences in the characteristics of the populations rather than to differences in the effect of place per se.

As with the findings on contraceptive knowledge, the association between being a migrant in the metro area and using contraceptives may be due to migrant selectivity or migrant adaptation. From previous research, ${ }^{15}$ we expected that migrants would adopt modern contraceptives fairly soon after migrating to the metro area (rather than gradually, as is the case with contraceptive learning), given the increased economic pressures to control fertility. However, the results from the third model, which included two dummy variables for duration of stay in an urban area, sugTABLE 5. Odds ratios from logistic regression models estimating the likelihood of
current use of modern contraceptives, by model

\begin{tabular}{|c|c|c|c|c|}
\hline Variable & Model 1 & Model 2 & Model 3 & Model 4 \\
\hline \multicolumn{5}{|l|}{ Migration } \\
\hline Rural nonmigrant (ref) & 1.00 & 1.00 & 1.00 & 1.00 \\
\hline \multicolumn{5}{|l|}{ Rural-urban migrant } \\
\hline In small urban area & 1.83 & 1.36 & 1.37 & 0.98 \\
\hline In metro area & $2.66^{* *}$ & $1.90^{*}$ & na & na \\
\hline \multicolumn{5}{|l|}{ Urban nonmigrant } \\
\hline In small urban area & $2.60^{*}$ & 1.43 & 1.44 & 1.42 \\
\hline In metro area & $4.38^{* *}$ & $2.72^{* *}$ & $2.74^{* *}$ & $1.91^{* *}$ \\
\hline \multicolumn{5}{|c|}{ Duration of stay in metro area } \\
\hline $1-5$ yrs. & na & na & 1.20 & 0.94 \\
\hline$\geq 6 \mathrm{yrs}$ & na & na & $2.17^{*}$ & 1.24 \\
\hline \multicolumn{5}{|c|}{ Contraceptive knowledge } \\
\hline No. of methods known & na & na & na & $4.60^{* *}$ \\
\hline \multicolumn{5}{|l|}{ Social and demographic } \\
\hline Mayan & na & $0.50^{* *}$ & $0.50 * *$ & $0.62^{* *}$ \\
\hline Age & na & $0.98^{* *}$ & $0.98^{* *}$ & $0.98^{* *}$ \\
\hline Male & na & & & \\
\hline \multicolumn{5}{|l|}{ Education } \\
\hline None (ref) & na & 1.00 & 1.00 & 1.00 \\
\hline Primary & na & $2.01 *$ & $2.02^{*}$ & $1.95^{*}$ \\
\hline Secondary & na & $2.55^{* *}$ & $2.53^{* *}$ & $2.07^{*}$ \\
\hline Postsecondary & na & $2.77^{* *}$ & $2.77^{* *}$ & 1.91 \\
\hline Woman/wife works & na & 0.89 & 0.89 & 0.88 \\
\hline Formal union & na & 1.38 & 1.36 & 1.32 \\
\hline \multicolumn{5}{|l|}{ Surviving children } \\
\hline 0 (ref) & na & 1.00 & 1.00 & 1.00 \\
\hline $1-4$ & na & $5.95^{* *}$ & $5.98^{* *}$ & $5.71^{* *}$ \\
\hline$\geq 5$ & na & $3.77^{* *}$ & $3.78^{* *}$ & $3.62^{*}$ \\
\hline Logpseudolikelihood & -596.5 & -552.8 & -552.2 & -496.5 \\
\hline
\end{tabular}

gest gradual adaptation rather than rapid adaptation or selectivity. The odds of currently using a modern contraceptive were more than twice as high among rural-to-urban migrants who have been in Guatemala City for more than five years than they were among rural nonmigrants (2.2), whereas recent migrants' contraceptive use did not differ significantly from that of rural nonmigrants. In addition, the odds of using a modern contraceptive method were almost three times as high among urban nonmigrants in the metropolitan area as they were among rural nonmigrants (2.7).

For our final model, we added a variable for contraceptive knowledge to determine how important knowledge is for current use and whether the pace of contraceptive learning is a factor in the likelihood of current contraceptive use among migrants. To reduce the potential problem of endogeneity (contraceptive use automatically requires knowledge of at least one method), we rescaled contraceptive knowledge into three categories: 0-1 methods, 2-4 methods and 5-10 methods. This rescaling follows the approach taken by DeGraff and others to modeling the effect of contraceptive knowledge on current contraceptive use. ${ }^{16}$

When contraceptive knowledge was added to the analysis (model 4), the odds of contraceptive use among migrants living in the metropolitan area for more than five years were not significantly different from those for rural nonmigrants. In addition, the odds of contraceptive use associated with being a nonmigrant in Guatemala City, being Ladino and having a primary or higher education decreased. These re- 
sults suggest that lack of knowledge and familiarity with modern contraceptive methods remains an important barrier to modern contraceptive use in Guatemala, particularly in the indigenous population. In addition, the ability of migrants to adopt urban contraceptive practices seems to be impeded by their limited contraceptive knowledge and, therefore, may be closely linked to the pace at which they learn about modern contraceptive methods in their new environment.

\section{DISCUSSION}

Compared with urban nonmigrants, individuals who migrate from rural areas to Guatemala City are less able to effectively control their fertility. On average, they are less educated and have lower levels of contraceptive knowledge and, if they migrate as adults, they begin their residence in the city with less knowledge of where and what reproductive health services are available. However, like urban natives, they encounter place-specific cost constraints on childbearing and childrearing. Research on the interrelationship of migration and fertility in developing countries often finds migrant fertility to be lower than that of rural nonmigrants, but still above levels of urban natives. ${ }^{17}$ A common explanation for the persistence of a fertility differential between migrants and natives, even after accounting for other factors, is that migrants do not fully assimilate in terms of urban fertility norms and practices.

Our results from Guatemala suggest that contraceptive knowledge may be another factor limiting migrants' adaptation to nonmigrant urban fertility levels, especially in countries where modern contraceptive use remains relatively low in rural areas. The migrants in our sample reached and even surpassed urban nonmigrants in terms of the numbers of modern contraceptive methods known, which suggests a strong interest among migrants in learning about and perhaps trying alternative contraceptive methods. The strong positive association between duration of residence in the metro area and contraceptive knowledge suggests that migrants arrive in the metro area with lower levels of contraceptive knowledge and then gradually acquire more knowledge of and familiarity with modern methods. If the demand for effective birth control increases more quickly than contraceptive knowledge, the level of unmet need will be fairly high during the initial period after migration.

Because of sample size limitations, we were unable to identify precisely at what duration of stay in the metro area the odds of modern contraceptive use among migrants rose above rural levels. We did find, however, that migrants who had lived in the metropolitan area for more than five years were more likely than rural nonmigrants to use modern contraceptives. Furthermore, the likelihood of modern contraceptive use is closely linked to contraceptive knowledge, which is accumulated over time.

Studies of rural-to-urban migration in developing countries often find that recently arrived migrants are spatially concentrated in areas of recent settlement. ${ }^{18}$ These areas are likely to have fewer reproductive health services than more settled areas. Our results suggest that unmet need may be greatest during the period soon after arrival. The spatial concentration of recent migrants in areas with poor services would make it easier to specifically target migrants for family planning interventions and suggests that interventions in such areas will potentially have the greatest impact on reducing unmet contraceptive need.

Our results highlight the importance of targeting migrants from ethnic groups that experience significant cultural and linguistic barriers to contraceptive awareness and adoption. Interventions designed to raise contraceptive awareness and use among migrant populations can have multiple payoffs. In addition to reducing unmet contraceptive need among migrant couples, interventions provide knowledge of modern contraceptive methods and practices that migrants may carry back to relatives and friends in their rural home communities. ${ }^{19}$ In addition, programs designed to raise awareness of HIV/AIDS and safer-sex practices can be incorporated into contraceptive outreach programs and thereby reduce the risk of HIV transmission in both urban destinations and rural home communities.

\section{REFERENCES}

1. Ministerio de Salud Pública y Asistencia Social (MSPAS), Guatemala: Encuesta Nacional de Salud Materno Infantil 2002, Guatemala City: MSPAS, 2003

2. Ibid.

3. Santiso-Galvez R and Bertrand J, The delayed contraceptive revolution in Guatemala, Human Organization, 2004, 63(1):57-67; and Seiber $E$ and Bertrand J, Access as a factor in differential contraceptive use between Mayans and ladinos in Guatemala, Health Policy and Planning, 2002, 17(2):167-177.

4. United Nations, World Urbanization Prospects: The 2003 Revision, New York: United Nations, 2004

5. Brockerhoff $M$ and Yang X, Impact of migration on fertility in SubSaharan Africa, Social Biology, 1994, 41(1-2):19-43; Martine G, Migrant fertility adjustment and urban growth in Latin America, International Migration Review, 1975, 9(2):179-191; and White M et al., Urbanization and the fertility transition in Ghana, Population Research and Policy Review, 2005, 24(1):59-83.

6. Bender DE, Rivera $\mathrm{T}$ and Madonna $\mathrm{D}$, Rural origin as a risk factor for maternal and child health in peri-urban Boliva, Social Science \& Medicine, 1993, 37(11):1345-1349; Carballo M, Grocutt M and Hadzihasanovic A, Women and migration: a public health issue, World Health Statistics Quarterly, 1996, 49(2):158-164; Shaokang Z, Zhenwei $\mathrm{S}$ and Blas $\mathrm{E}$, Economic transition and maternal health care for internal migrants in Shanghai, China, Health Policy and Planning, 2002, 17(Suppl. 1):47-55; and Stephenson R et al., The impact of rural-urban migration on under-two mortality in India, Journal of Biosocial Science, 2003, 35(1):15-31.

7. Brockerhoff M, Fertility and family planning in African cities: the impact of female migration, Journal of Biosocial Science, 1995, 27(3):347358.

8. Instituto Nacional de Estadística (INE), Guatemala: Encuesta Nacional de Salud Materno Infantil 1995, Guatemala City: INE, 1996; INE, Guatemala: Encuesta Nacional de Salud Materno Infantil 1998-1999, Guatemala City: INE, 1999; and MSPAS, 2003, op. cit. (see reference $1)$.

9. Coffee MP et al., Patterns of movement and risk of HIV infection in rural Zimbabwe, Journal of Infectious Diseases, 2005, 191(Suppl. 1):S159-S167; Lagarde E et al., Mobility and the spread of human immunodeficiency virus into rural areas of West Africa, International Journal of Epidemiology, 2003, 32(5):744-752; Simonet D, The AIDS epidemic and migrants in South Asia and South-East Asia, International 
Migration, 2004, 42(5):35-67; and Yang X, The fertility impact of temporary migration in China: a detachment hypothesis, European Journal of Population, 2000, 16(2):163-183.

10. Brockerhoff M, Migration and fertility transition in African cities, in: Bilsborrow RE, ed., Migration, Urbanization, and Development: New Directions and Issues, Norwell, MA, USA: Kluwer Academic Publishers, 1998, pp. 357-392.

11. Lindstrom DP and Muñoz-Franco E, Migration and the diffusion of modern contraceptive knowledge and use in rural Guatemala, Studies in Family Planning, 2005, 36(4):277-288.

12. Brockerhoff M, 1998, op. cit. (see reference 10).

13. Bastos S and Camus M, Los Mayas de la Capital: Un Studio Sobre Identidad Étnica y Mundo Urbano, Guatemala City: Facultad Latinoamericana de Ciencias Sociales (FLACSO), 1995; Camus M, Ser Indigena en Ciudad de Guatemala, Guatemala City: FLACSO, 2002; and Pérez Sainz JP, Camus M and Bastos S, Todito, Todito es Trabajo. Indígenas y Empleo en Ciudad de Guatemala, Guatemala City: FLACSO, 1992.

14. Bertrand J et al., Promoting birthspacing among the Maya-Quiché of Guatemala, International Family Planning Perspectives, 1999, 25(4): 160-167; and Bertrand JT, Seiber E and Escudero G, Contraceptive dynamics in Guatemala: 1978-1998, International Family Planning Perspectives, 2001, 27(3):112-118.

15. Brockerhoff M, 1998, op. cit. (see reference 10).

16. DeGraff DS, Increasing contraceptive use in Bangladesh: the role of demand and supply factors, Demography, 1991, 28(1):65-81; Hogan DP, Berhanu B and Hailemariam A, Household organization, women's autonomy, and contraceptive behavior in Southern Ethiopia, Studies in Family Planning, 1999, 30(4):302-314.

17. Lindstrom DP, Rural-urban migration and reproductive behavior in Guatemala, Population Research and Policy Review, 2003, 22(4):351372

18. Bastos S and Camus M, 1995, op. cit. (see reference 12); and Camus M, 2002, op. cit. (see reference 12).

19. Lindstrom D and Muñoz-Franco E, 2005, op. cit. (see reference 11).

\section{RESUMEN}

Contexto: Son bastante diferentes los niveles de conocimiento y el uso de anticonceptivos modernos entre las personas que residen en las zonas rurales de Guatemala y aquellas radicadas en los centros urbanos. Es importante comprender el ritmo y la medida en que las personas que emigran del campo a la ciudad adoptan las prácticas anticonceptivas de la ciudad para determinar si hay una necesidad sólida de concentrar los programas de salud reproductiva en los grupos migratorios.

Métodos: Se utilizaron análisis bivariados y multivariados con los datos obtenidos en base a entrevistas a 971 hombres y mujeres casadas que participaron en la Encuesta sobre Salud Reproductiva a Emigrantes Rurales en Guatemala en 1999, para determinar la relación entre la condición y duración de la residencia urbana y el conocimiento de métodos anticonceptivos modernos y el uso actual de dichos métodos.

Resultados: El nivel de conocimientos sobre anticonceptivos de los migrantes estuvo relacionado positivamente con el número de años que tenían de residencia en una zona urbana. Los migrantes de origen maya en la ciudad de Guatemala no adquirian los conocimientos sobre anticonceptivos con la misma rapidez que los migrantes no mayas, probablemente debido a las barreras culturales y lingüisticas que impedian su conocimiento y acceso a los métodos anticonceptivos. Los migrantes de las zonas rurales a los centros urbanos eventualmente presentaban un nivel de conocimientos sobre métodos anticonceptivos modernos un poco menor que las personas que habian nacido en la ciudad; el nivel de conocimientos de anticonceptivos es un importante factor con respecto al uso de los métodos modernos.

Conclusiones: Durante sus primeros años de residencia en los centros urbanos, los migrantes poseen un limitado conocimiento sobre los métodos anticonceptivos modernos; por lo tanto, es posible que tengan una necesidad insatisfecha de anticonceptivón y que dispongan de un número limitado de opciones de anticonceptivos moderno. Los programas dirigidos a propagar el conocimiento y uso de métodos anticonceptivos deben concentrar la atención en los migrantes recientes-en particular los indígenas mayas-en los centros urbanos.

\section{RÉSUMÉ}

Contexte: Les niveaux de connaissance et de pratique de la contraception moderne parmi les habitants des régions rurales du Guatemala diffèrent substantiellement de ceux des régions urbaines. Il importe de comprendre le rythme et l'étendue de l'adoption, par les migrants des milieux ruraux vers les centres urbains, des pratiques contraceptives urbaines, afin de déterminer l'importance du besoin de programmes de santé reproductive axés sur les migrants.

Méthodes: Les analyses bi-et multivariées des données relatives à 971 hommes et femmes mariés ayant répondu à l'enquête guatémaltèque de 1999 sur la migration et la santé reproductive ont servi à examiner l'association entre, d'une part, l'état de migrant et la durée de résidence en milieu urbain et, d'autre part, la connaissance des méthodes contraceptives modernes et la pratique courante de la contraception.

Resultats: La connaissance contraceptive des migrants s'est avérée positivement associée au nombre d'années vécues en milieu urbain. Les migrants mayas de Guatemala City se sont révélés ne pas acquérir leur connaissance de la contraception au même rythme que leurs homologues non mayas, en raison peutêtre d'obstacles culturels et linguistiques à l'obtention de cette connaissance et à l'accès aux contraceptifs. Les migrants des régions rurales vers les villes finissent par atteindre un niveau de pratique de la contraception moderne légèrement inférieur à celui des natifs des milieux urbains, le niveau de connaissance de la contraception s'avérant un facteur important de pratique des méthodes modernes.

Conclusions: Les migrants possèdent une connaissance limitée des méthodes contraceptives modernes. Ils peuvent par conséquent présenter un besoin non satisfait de contraception ou ne disposer que d'un choix limité de méthodes modernes durant leurs premières années de vie en milieu urbain. Les programmes visant à accroître la sensibilisation à la contraception et sa pratique devraient cibler les migrants récents-d'origine indigène maya en particulier-dans les milieux urbains.

\section{Acknowledgments}

This research was supported by grant SES-0079581 from the National Science Foundation.

Author contact: David_Lindstrom@brown.edu 